\title{
Colin P. Groves (1942-2017) and his legacy
}

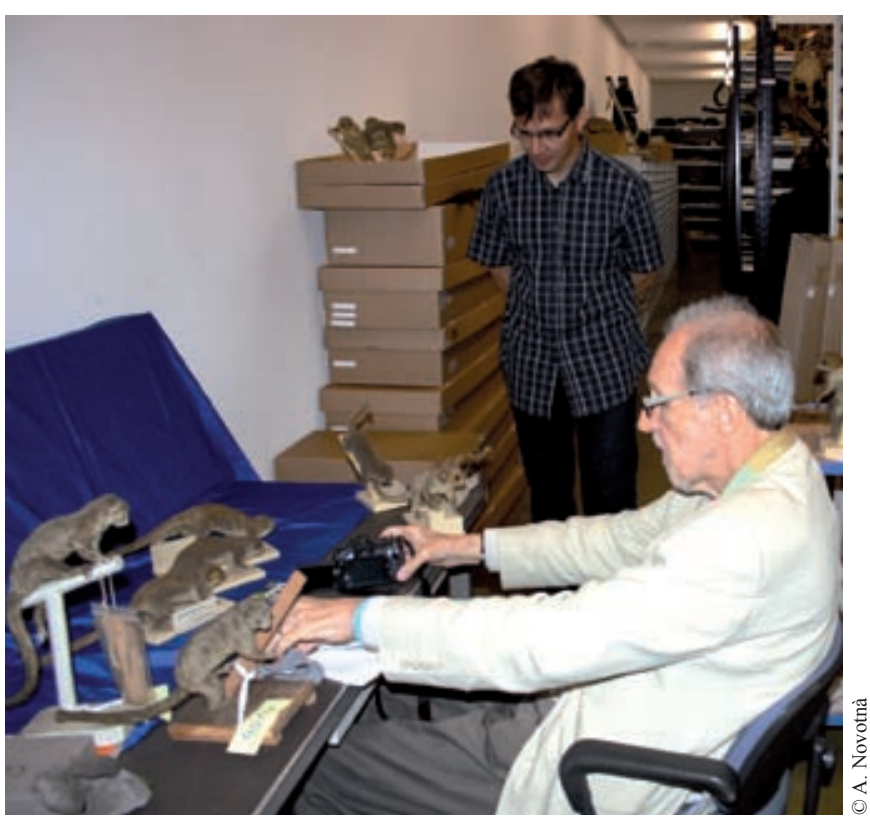

Colin Peter Groves was born in London, England, on June 24, 1942. He received his Bachelor of Science from University College London in 1963 and his Ph.D. from the Royal Free Hospital School of Medicine in 1966. While studying gorilla taxonomy under the supervision of John Napier, he had the good fortune to meet Osman Hill, Sherry Washburn, Louis Leakey and Wilfred Le Gros Clark, all of them famous researchers in the field of Anthropology and Primatology. Equally important to Colin, as he recalled in Groves (2008), was his meeting with Guy, the lone male silverback gorilla - then at London Zoo. After a series of post-doctoral research and teaching appointments at Cambridge University, he spent from 1974 the remainder of his career at the Australian National University with his beloved wife Phyll Dance. Colin received many awards: he was a Fellow of the Australian Academy of the Humanities, an Honorary Life Member of the American Society of Mammalogists, and in 2015 he received the Osman Hill Medal of the Primate Society of Great Britain. In the same year, Colin was the honoree of a volume entitled Taxonomic Tapestries: The Threads of Evolutionary, Behavioural, and Conservation Research (Behie \& Oxenham, 2015). He also served in the editorial board of several scientific journals, including Natural History Sciences. Atti della Società Italiana di Scienze Naturali e del Museo Civico di Storia Naturale in Milano.

Colin was one of the world's leading mammal taxonomists and biological anthropologists. He identified more than 50 new species of mammals during his career - the last was the Tapanuli Orangutan Pongo tapanuliensis from Sumatra (Nater et al., 2017) - and he also re-evaluated

\section{Spartaco Gippoliti}

\author{
Società Italiana per la Storia della Fauna "Giuseppe Altobello", \\ Viale Liegi 48, 00198 Roma, Italia. \\ E-mail: spartacolobus@hotmail.com \\ (C) 2018 Spartaco Gippoliti
}

Received: 20 December 2017

Accepted for publication: 13 February 2018 some hundreds of species names which had fallen into synonymy or had been overlooked with the passage of time, such as Grauer's gorilla Gorilla beringei graueri (Groves, 1970). He became well known for his revised classification of Primates, and his studies on the variation and evolution of living primates, described in detail in his book Primate Taxonomy (Groves, 2001). Along with the Czech zoologist Vratislav Mazák, he was the describer of a new species of hominid, Homo ergaster (Groves \& Mazák, 1975).

For decades, Colin worked closely with his friend Peter Grubb (1942-2006), whose contributions in mammalian taxonomy and biogeography were encyclopedic and wide ranging (Groves, 2006). Groves and Grubb conducted a long-term program to revise all the 'ungulates' (Perissodactyla and Artiodactyla): finally published in the influential volume Ungulate Taxonomy (Groves \& Grubb, 2011). In the meantime, they published widely on many taxa. Their revisions of two genera of megaherbivores stand tall. By 1999, they had revised the African elephants and demonstrated why distinctive morphological differences justified the full species status of Loxodonta cyclotis (Grubb et al., 2000). This was several years before molecular evidence consolidated their findings (Rohland et al., 2010) Colin, with the help of Jan Robovský and Prithiviraj Fernando, also revised the rhinoceros genus Ceratotherium, elevating the northern subspecies cottoni of the White rhinoceros ( $C$. simum) to species rank (Groves et al., 2010).

Colin once recalled a visit to the Natural History $\mathrm{Mu}-$ seum in London with his father when he was five years of age - and how this was an important milestone which led to his interest in the natural world. Although he had 
fascinating experiences in the field among mountain gorillas and the Tana River endemic primates, among others, it was the major museum collections that opened up to him a unique insight of mammalian evolution and diversity. I emphasize this because the importance of museum collections is often overlooked, especially in Western Europe, while their value is immense, especially when examined and re-interpreted by expert taxonomists like Colin. His was a true mentor to all his students in Canberra and several others around the world. His generosity and wide knowledge is well illustrated by these words of a former student; "One of my favourite memories of Colin was when I was hunting for some literature to assist my research, and all I could find was a thesis in German. I was showing it to Colin and lamenting that it was not much use, but he looked at me surprised and asked 'Do you not speak German?'. I shook my head, to which Colin promptly took out his reading glasses and started to translate the work for me there and then on the spot. His talents knew no bounds!".

Colin Groves was an inspiration to modern mammalogists, conservationists and evolutionary biologists because his interests looked beyond the most 'fashionable' species of the world, such as gorillas, rhinoceroses and tigers, to some of the most poorly taxa of mammals - such as tragulids, colobines and tarsiers (Groves, 2007; Groves, \& Shekelle, 2010; Meijaard \& Groves, 2004). Colin was incredibly generous with his time and often helped non-native English speaking scientists (even if he was not formally collaborating or an author on the papers) with their prose. Further, he was not put off from contributing to obscure newsletters, always aiming at advancing knowledge and conservation awareness across multiple audiences. The importance of Colin's taxonomic research in relation to conservation, including ex situ conservation, was immediately clear to me, probably because of my early experiences with the large number of mammalian species kept in zoological gardens. This also made me aware of how some apparently well-established mammal species may hide overlooked taxonomic entities often in need of urgent protection. Over the past six years, with like-minded colleagues, Colin and I collaborated with the aim of increasing acceptance of the "Phylogenetic Species Concept" among mammalogists (especially in Europe and Australia); moreover, we strived to demonstrate that the 'taxonomic inflation' theory (which suggests negative conservation outcomes when former subspecies are elevated to species rank) was in fact deleterious for biodiversity conservation (Cotterill et al., 2017, Gippoliti et al., 2018). Although Colin's health declined seriously during the last few years, he maintained his exceptional productivity while continuing to help his friends, colleagues and new contacts. Our 'team' had in the meantime grown in number and was able to provide a synthesis on species concepts and conservation (Groves et al., 2017). Colin worked until a few days before he died, on 30 November 2017. Now I can only share the words of Jan Robovský "Yes, Colin [friendship] made our lives privileged and much better, I think. As Colin was always encouraging us, one could lose some portion of motivation now, but being obliged to follow [Colin's way], one should try to continue our mission in accord with Colin's legacy".

\section{Acknowledgements}

David Happold, Fenton Cotterill and two anonymous reviewers greatly improved the original manuscript.

\section{REFERENCES}

Behie A. M. \& Oxenham M. F. (eds.), 2016 - Taxonomic Tapestries: The Threads of Evolutionary, Behavioural, and Conservation Research. Australian National University Press, Canberra.

Cotterill F. P. D., Groves C. P. \& Taylor P. J., 2017 - Taxonomy: refine rather than stabilize. Nature, 547: 162.

Gippoliti S., Cotterill F. P. D., Zinner D. \& Groves C. P., 2018 - Impacts of taxonomic inertia for the conservation of African ungulate diversity: an overview. Biological Reviews, 93: 115-130.

Groves C. P., 1970 - Population systematics of the gorilla. Journal of Zoology, 161 (3): 287-300.

Groves C. P., 2001 - Primate Taxonomy. Smithsonian Institution Press, Washington.

Groves C. P., 2006 - Tribute to Peter Grubb. Suiform Soundings, 6 (2): 4.

Groves C. P., 2007 - The taxonomic diversity of the Colobinae of Africa. Journal of Anthropological Sciences, 85: 7-34.

Groves C. P., 2008 - Extended Family: long lost cousins. A personal look at the history of primatology. Conservation International, Arlington.

Groves C. P., Cotterill F. P. D, Gippoliti S., Robovský J., Roos C., Taylor P. J. \& Zinner D., 2017 - Species definitions and conservation: a review and case studies from African mammals. Conservation $\mathrm{Ge}-$ netics, 18: 1247-1256.

Groves C. P., Fernando P. \& Robovský J., 2010 - The sixth rhino: a taxonomic re-assessment of the critically endangered northern white rhinoceros. PLoS ONE, 5:e9703. < doi:10.1371/journal/ pone.0009703>

Groves C. P. \& Grubb P., 2011 - Ungulate Taxonomy. John Hopkins University Press, Baltimore.

Groves C. P. \& Mazák V., 1975 - An approach to the taxonomy of the Hominidae: gracile Villafranchian hominids of Africa. Časopis pro Mineralogii a Geologii, 20: 225-247.

Groves C. P. \& Shekelle M., 2010 - The genera and species of Tarsiidae. International Journal of Primatology, 31: 1071-1082.

Grubb P., Groves C. P., Dudley J. P. \& Shoshani J., 2000 - Living African elephants belong to two species: Loxodonta africana (Blumenbach, 1797) and Loxodonta cyclotis (Matschie, 1900). Elephant, 2: $1-3$.

Meijaard, E. \& Groves C. P., 2004 - A taxonomic revision of the Tragulus mouse-deer (Artiodactyla). Zoological Journal Linnean Society, 140: 63-102.

Nater A., Mattle-Greminger M. P., Nurcahyo A., Nowak M. G., de Manuel M., Desai T., Groves C., Pybus M., Sonay T B., Roos C., Lameira A. R., Wich S. A., Askew J., Davila-Ross M., Fredriksson G., de Valles G., Casals F., Prado-Martinez J., Goossens B., Verschoor E. J., Warren K. S., Singleton I., Marques D. A., Pamungkas J., Perwitasari-Farajallah D., Rianti P., Tuuga A., Gut I. G., Gut M., Orozco-terWengel P., van Schaik C. P., Bertranpetit J., Anisimova M., Scally A., Marques-Bonet T., Meijaard E. \& Krützen M., 2017 - Morphometric, behavioral, and genomic evidence for a new Orangutan species. Current Biology, 27 (22): 3487-3498.

Rohland N., Reich D., Mallick S., Meyer M., Green R. E., Georgiadis N. J., Roca A. L. \& Hofreiter M., 2010 - Genomic DNA sequences from mastodon and woolly mammoth reveal deep speciation of forest and savanna elephants. PLoS Biology, 8 (12): e1000564. 